\title{
Aesthetics of Semar Figure in Ki Sukasman's Wayang Ukur
}

\author{
Yayah Rukiah $^{1}$, Sarwanto $^{2}$, Soetarno $^{3}$, Sunardi $^{4}$ \\ \{rukiah.yayah13@gmail.com ${ }^{1}$, sarwanto@isi-ska.ac.id ${ }^{2}$,tarno_dea@yahoo.com ${ }^{3}$ \} \\ Institut Seni Indonesia Surakarta, Indonesia ${ }^{1234}$
}

\begin{abstract}
Wayang is one of the innovations in wayang. Ki Sukasman creates a new wayang creation which is a new theory in the field of Indonesian wayang art. Ki Sukasman conducted several experiments to find the perfection of form in the wayangukur. This article aims to examine the aesthetics of the Semar figure in $\mathrm{Ki}$ Sukasman's wayangukur. This study uses an aesthetic approach with a qualitative method. The results obtained are the aesthetics of the shape of the shadow puppets are very different from the wayang kulit in general. Semar in Ki Sukasman's wayang measuring refers to the anatomy of the human body which is depicted in real terms.
\end{abstract}

Keywords: aesthetics, Semar figures, wayang ukur

Estetika Figur Semar pada Wayang Ukur Karya Ki Sukasman

\begin{abstract}
Abstrak. Wayang ukur salah satu inovasi dalam pewayangan. Ki Sukasman menciptakan wayang kreasi baru yang merupakan teori baru dalam bidang senirupa wayang Indonesia. Ki Sukasman melakukan beberapa eksperimen untuk menemukan kesempurnaan bentuk pada wayang ukur. Artikel ini bertujuan untuk mengkaji estetika dari figur Semar pada wayang ukur karya Ki Sukasman. Penelitian ini menggunakan pendekatan estetika dengan metode kualitatif. Hasil yang didapat adalah estetika bentuk pada wayang ukur sangat berbeda dengan wayang kulit pada umumnya. Semar pada wayang ukur Ki Sukasman mengacu pada anatomi tubuh manusia yang digambarkan secara nyata.
\end{abstract}

Kata kunci: estetika, figur Semar, wayang ukur

\section{Pendahuluan}

Peter Salim mengartikan wayang merupakan mainan anak-anakan berupa manusia, yang terbuat dari ukiran kayu, kulit kerbau, dan lain-lain. Wayang digunakan pada suatu tontonan tradisional sebagai tokoh tertentu di wilayah Bali, Jawa, juga wilayah lainnya, yang dimainkan oleh seorang dalang [1]. Sedangkan menurut Kamus Lengkap Bahasa Jawa, belulang digunakan untuk membuat duplikat manusia yang disebut wayang [2]. Wayang pada dasarnya adalah karya seni rupa yang mempunyai makna dan juga merupakan lambang atau simbol kehidupan. Wayang juga merupakan unsur penting di dalam kebudayaan Jawa dan berpengaruh kuat dalam hidup budaya masyarakat Jawa [3]. Perkembangan nilai pertunjukan wayang di Pulau Jawa sangat berarti. 
Eksistensi Wayang Ukur merupakan bukti dari upaya mengembangkan kesenian wayang yang ada di Pulau Jawa. Bermula dari kekhawatiran Ki Sigit Sukasman di tahun 80-an akan mulai pudarnya minat generasi muda saat ini akan pagelaran wayang kulit. Bentuk wayang ukur yang dibuat Ki Sukasman sangat berbeda dengan wayang kulit pada umumnya, jika dipandang melalui sudut kesenirupaan terdapat elemen-elemen desain yang sangat khas.

Artikel yang ditulis oleh Salim mengenai eksplorasi bentuk dari wayang ukur ciptaan Ki Sukasman, menerangkan bahwa hadirnya wayang ukur karya Ki Sukasman salah satu kreasi baru pada bentuk wayang. Ki Sukasman melakukan perubahan bentuk yang menitikberatkan pada wujud rupa wayang kulit purwa gaya Surakarta dan Yogyakarta, juga komposisi, warna dan keseimbangan.

Ki Sukasman menciptakan wayang ukur figur wayang Punakawan dengan wujud rupatokoh Semar, Gareng, petruk dan Bagong yang berbeda. Punakawan secara karakteristik mewakili profil manusia, Punakawan memiliki karakter yang mewakili simbol kerendahhatian dan penebar hikmah [4]. Artikel ini akan membahas estetika dari salah satu tokoh Punakawan pada wayang ukur yaitu Semar. Semar merupakan tokoh yang sangat istimewa. Semar dikenal sebagai abdi dan juga pamomong. Bentuk figur Semar menyimbolkan kehidupan. Tujuan dari penulisan ini adalah untuk mengungkap makna figur Semar pada wayang ukur Ki Sukasman.

\section{Metode}

Artikel ini menggunakan metode kualitatif deskripsi pendekatan estetika. Penelitian dengan metode ini, sering kali data yang didapat sangat banyak dan tidak tersusun, hal ini mengharuskan mengolah data dengan memilah, mengkaji dan mengolong-golongkan [5]. Estetika digunakan untuk melihat bentuk dari figur Semar dan makna yang terkandung di dalamnya. Figur Semar dikaji menggunakan estetika dengan melihat bentuk dan atribut yang digunakan pada wayang ukur Ki Sukasman dari garis, bidang, tatahan dan sunggingan. Artikel ini menggunakan studi literatur, berupa artikel dan buku, untuk mengkaji wayang ukur Figur Semar karya Ki Sukasman.

\section{Hasil dan Pembahasan}

Kreativitas seniman wayang bernama Sukasman atas kecintaan dan fokusnya pada perkembangan wayang kulit purwa gaya Surakarta dan Yogyakarta dapat melahirkan inovasi wayang yaitu wayang ukur. Pada tahun 1974 Sukasman menciptakan wayang ukur ini, dengan menitikberatkan pada rupa figur wayang kulit purwa gaya Surakarta dan Yogyakarta [6]. Wayang ukur Sukasman memiliki rupa yang berbeda dan unik dengan nilai estetik yang tinggi. Keistimewaan ini terlihat pada rupa, sunggingan dan tatahan yang terlihat berbeda dengan wayang kulit purwa lainnya. Rupa dan teknik tatah sungging yang berbeda pada wayang ukur merupakan kreasi baru yang dilakukan Sukasman. Wayang kreasi, menurut Pratama [7], yaitu perubahan dari lakon dan rupa wayang yang tidak lagi sesuai dengan pakem baik perbagian ataupun seluruhnya merupakan wayang hasil ciptaan dengan kreasi baru. Saat ini, masyarakat modern sudah mulai meninggalkan wayang tradisi oleh sebab itu dibutuhkan diciptakannya wayang dengan kreasi baru. Tertinggalnya wayang tradisi dikarenakan adanya perkembangan zaman yang menyebabkan ketidaksesuaian dengan kondisi, karena pertunjukan 
wayang tradisi, lihat kaku dari lakon, Bahasa yang digunakan terlebih durasi pertunjukan yang sangat lama.

Menurut Ali dalam Sunarto dalam Suyanto [8], kreasi merupakan ciptaan atau khayalan atau juga hasil pemikiran manusia. Arti dari kata baru ialah yang sebelumnya tidak ada. Maka, pengertian dari wayang kulit kreasi baru yaitu wayang yang dirancang oleh manusia dan sebelumnya tidak ada. Wujud rupa wayang ukur Sukasman lebih menitikberatkan pada bagian atas sampai pinggang, khusus pada rupa mata, mulut dan hidung, lalu rupa leher dan tangan. Sedangkan rupa kain dibuat lebih menjulur ke bawah. Penggambaran jari-jari dibuat lebih realis. Begitu juga rupa figur Semar sangat berbeda dengan wayang kulit pada umumnya.

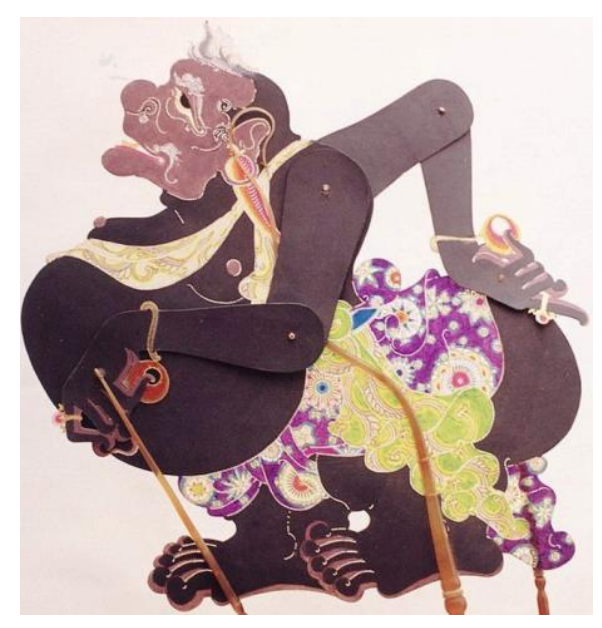

Gambar 1. Semar Wayang Ukur Sukasman

Sumber : http://tokohwayangpurwa.blogspot.com/2012/09/semar-gaya-ukur.html

Wayang ukur Sukasman merupakan karya ekspresi individu Ki Sukasman, tetapi wanda perupaan wayang yang menjadi ciri setiap tokoh dalam wayang tidak ditinggalkan, sehingga saat melihat figur wayang ukur, orang masih bisa mengenalinya. Ki Sukasman membuat analisis dari dasar perupaan wayang, yaitu perbandingan dan posisi ukuran tubuh. Pada perbandingan itu (proporsi manusia dengan wayang) akhirnya dapat dilihat adanya evolusi pada wajah, kepala, bahu yang semakin melebar, kepala lebih besar, tangan lebih panjang, serta tubuh yang lebih ramping [9]. Ini bisa terlihat pada wayang Semar. Wayang Semar karya Sukasman dengan wayang Semar lainnya berbeda. Hal tersebut dapat dilihat dari bentuknya karena wayang ukur menekankan kejelasan pada bentuk anatomi tubuh manusia. Jika dilihat dari jarak yang cukup jauh, tetap terlihat dengan jelas bentuk wayangnya. Di bawah ini bentuk wayang Semar karya Ki Sukarman dengan wayang Semar karya Ki Bambang Suwarno. 


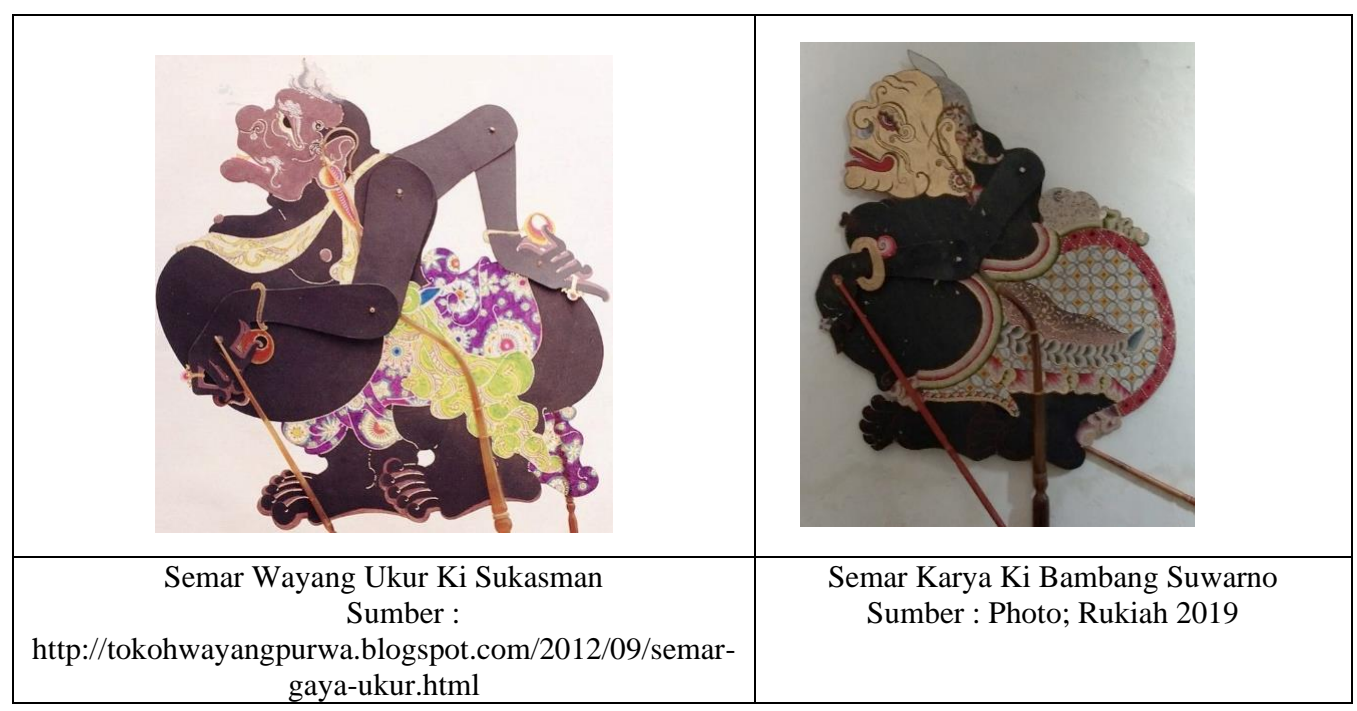

Dalam membuat wayang ukur Semar Sukasman sangat bebas dalam berkreasi. Wayang ukur Semar di atas (gambar 1) adalah Semar yang diciptakan Ki Sukasman di tahun 2007 yang merupakan karya ke 4. Ukuran figur Semar ini sudah disesuaikan dan diperhitungkan dengan seksama, dengan ukuran lebar dan tinggi terpaut $1 \mathrm{~cm}$ yaitu $39 \mathrm{~cm}$ dan $38 \mathrm{~cm}, 33,5 \mathrm{~cm}$ untuk ukuran Panjang tangan dan 4,5 untuk lebarnya, sedangkan 16,5 cm untuk ukuran antara dagu ke rambut. Kulit digunakan untuk mengkaitkan tangan. Jarak dari perut ke bokong $35 \mathrm{~cm}$, sedangkan kuntung berukuran $14 \mathrm{~cm}$. [10]. Semar ini dengan bentuk pantat dan perut bulat besar dan gemuk, menggenakan selempang di pundak, juga kaki lebih pendek dan gempal.

Bentuk perut dan pantat Semar menyimbolkan dunia bagian Barat dan Timur. Jari-jari pada kaki dibuat semi realis, posisi letak ibu jari pada wayang ini digambarkan di bawah untuk kaki depan dan posisi atas untuk bagian belakang, jadi posisi kaki kanan dan kiri terlihat jelas. Pewarnaan juga dibuat berbeda pada telapak kaki. Pada wayang ukur Semar, sangat terasa sekali harmonisasi pewarnaannya. Pakaian Semar yang sangat modern. Jarik yang digunakan adalah motif lingkaran (seperti matahari) yang dikombinasikan dengan motif geometris, dengan warna-warna cerah yang berbeda dengan warna wayang pada umumnya. Selempang yang digunakan berwarna putih dengan ornamen warna hijau kuning. Makna dari selempang Semar memiliki kemurnian hati dan jiwa, sedangkan motif jarik simbol dari kehidupan.

Sembuliyan tunggal yang dikenakan wayang Semar dengan warna kuning dan hijau, memakai aksesoris cincin pada jari telunjuk kanan dan kiri, juga tangan mengenakan perhiasan gelang yang berbentuk seperti mainan yoyo dengan warna merah dan kuning. Tangan kanan Semar yang menunjuk memiliki makna bahwa Semar selalu menunjuk yang baik dan benar. Telapak tangan dibuat dengan warna berbeda dari warna lengan, warnanya coklat. Telinga Semar memakai anting-anting dengan bentuk lombok abang besar atau cabai warna merah. Hal tersebut menyimbolkan. Wayang Semar ini berbeda dengan Semar pada umumnya karena terdapat umbel di hidung, ada air liur pada bagian pinggir bibir dan alis yang diberi warna putih. Wajah diberi warna coklat, kuncung dicat warna putih dibuat panjang melengkung ke atas, dengan rambut bagian belakang kepala berwarna hitam. Gambaran keseluruhan wajah Semar disebut sumeh. Penggambaran mulut tersenyum dengan mata seperti habis nangis dimaknai dalam hidup pasti ada suka maupun duka. Di kepala Semar terdapat 
kuncung dengan wajah orangtua menyimbolkan tua dan muda. Dada Semar ini lebih kecil dibanding Semar pada umumnya, lingkar perut lebih besar dari pantatnya dan posisi puser agak ke atas. Badan Semar dibuat dengan warna hitam yang melambangkan bumi, di mana tempat umat manusia tinggal (jagat raya). Semar juga merupakan simbol masyarakat Jawa.

\section{Simpulan}

Wayang ukur Ki Sukasman merupakan salah satu wayang kreasi. Penciptaan wayang kreasi dimulai dari masyarakat modern yang sudah meninggalkan pakem wayang karena melihat kondisi dan perkembangan zaman yang sudah tidak sesuai. Ki Sukasman, dalam membuat wayang ukur, melalui ekperimen-eksperimen untuk menemukan bentuk yang sesuai. Bentuk wayang ukur Ki Sukasman tidak sama dengan bentuk umum wayang karena wayang ukur disesuaikan pada proporsi tubuh manusia. Wayang ukur Semar Ki Sukasman sangat berbeda, dari bentuk, tatahan dan sunggingannya. Wayang ukur Semar nomor 4 yang dibuat Ki Sukasman menggunakan warna yang harmonis, bentuk kaki terlihat seperti kaki kanan dan kiri juga terdapat perbedaan warna untuk telapak kaki juga telapak kanan. Bentuk perut lebih besar dari pantat, dan badan Semar dibuat dengan warna hitam yang melambangkan bumi.

\section{Referensi}

[1] Ahmadi A. Kriya Wayang Kulit Purwa Gaya Surakarta Identifikasi Pola, Aneka Tatahan dan Sunggingannya. Surakarta: ISI Press Surakarta; 2016.

[2] Sudarmanto. Kamus Lengkap Bahasa Jawa. Semarang: Widya Karya; 2017.

[3] Hardjowirogo. Sejarah Wayang Purwa. Jakarta: PN Balai Pustaka; 1982.

[4] Kresna A. Punakawan: Simbol kerendahan hati orang Jawa. Yogyakarta: Narasi; 2012.

[5] Endraswara S. Metodelogi Penelitian Kebudayaan. 2003.

[6] Salim. Wayang Ukur Karya Sukasman Studi Ekplorasi Bentuk. Eksplanasi. 2011; Vol. 6 No.:78-93.

[7] Pratama D. Wayang Kreasi: Akulturasi Seni Rupa dalam Penciptaan Wayang Kreasi Berbasis Realitas Kehidupan Masyarakat. Deiksis [Internet]. 2011;Vol 3 No.:379-96. Available from: https://journal.lppmunindra.ac.id/index.php/Deiksis/article/view/442/741

[8] Suyanto E. Perbandingan Karakteristik Antara Tokoh Panakawan Wayang Kulit Purwa Gaya Yogyakarta Dengan Wayang Ukur Karya Sigit Sukasman [Internet]. Universitas Negeri Yogyakarta; 2012. Available from: http://eprints.uny.ac.id/id/eprint/22982

[9] Sukirno. Mengukur Wayang Ukur Karya Ki Sukasman. Brikolase J Kaji Teor Prakt dan Wacana Seni Budaya Rupa [Internet]. 2010; Vol 2,No 2. Available from: https://jurnal.isi-ska.ac.id/index.php/brikolase/article/view/309/311

[10] Senawangi TP. Ensiklopedi Wayang Indonesia. Jakarta: Senawangi; 1999. 